\title{
Hormone-Sensitive Lipase in Human Adipose Tissue, Isolated Adipocytes, and Cultured Adipocytes
}

\author{
FETUS O. ADEBONOJO, ${ }^{(59)}$ PAUL M. COATES, AND JEAN A. CORTNER \\ Joseph Stokes, Jr. Research Institute, The Children's Hospital of Philadelphia, Philadelphia, Pennsylvania and the \\ Department of Pediatrics, University of Pennsylvania, School of Medicine, Philadelphia, Pennsylvania, USA
}

\begin{abstract}
Summary
Employing a perifusion technique, the activity of hormone-sensitive lipase (HSL) in human adipose tissue and isolated adipocytes was found to be significantly stimulated by $5 \mu \mathrm{M}$ epinephrine (5fold, $P<0.001$ ) or $0.5 \mathrm{mM}$ theophylline (2-fold, $P<0.03$ ). The stimulatory effect of both, however, was not cumulative; instead, theophylline appeared to blunt the epinephrine effect. The two effectors together produced a 3-fold increase in activity over basal $(P<0.01)$. Basal lipolysis was highly and significantly correlated with epinephrine and/or theophylline stimulated lipolysis in the tissue as well as in the isolated cells.

The activity of the enzyme was examined in cultured human adipocytes using a cell-free system. The basal activity of HSL in the $20,000 \times g$ supernatant $\left(S_{20}\right)$ fraction of cultured cells grown in fat-enriched medium was significantly higher than the value in the same fraction of cells grown in regular medium $(6.06 \pm 1.49$ versus $2.78 \pm 0.89 \mathrm{nmole}$ glycerol $/ \mathrm{min} / \mathrm{mg}$ protein, mean \pm S.D. $P<0.01$ ), and was similar in the $S_{20}$ fractions of cells grown in the enriched medium and the original tissue $(6.06 \pm 1.49$ versus 5.44 $\pm 2.73 \mathrm{nmole}$ glycerol $/ \mathrm{min} / \mathrm{mg}$ protein, mean $\pm \mathrm{S} . \mathrm{D}$., $P>\mathbf{0 . 8 3}$ ). When the tissue and cells were stimulated in vitro before fractionation, the HSL activity in the $S_{20}$ fraction of the original tissue increased 4-fold over basal $(P<0.001)$, whereas that in the cultured cells increased 2 -fold $(P<0.01)$ regardless of the culture medium employed. In the $S_{20}$ fractions derived from basally incubated samples, but not in those derived from the epinephrinestimulated samples, the HSL enzyme was slightly but significantly $(P<0.002)$ activated by exogenous addition of ATP, cyclic AMP, and protein kinase.
\end{abstract}

The data suggest that the activity of HSL is retained in cultured human adipocytes and could be enhanced under conditions of culture which favor lipid accumulation and adipose conversion.

\section{Speculation}

Although the hormone-sensitive lipase enzyme protein in adipose tissue of the rat and the chicken has been extensively purified, the human enzyme remains difficult to purify. The finding in this study, that human adipose tissue hormone-sensitive lipase activity is retained in culture, should facilitate the purification and characterization of the enzyme in man, promote the study of the cellular mechnisms involved in the synthesis, transport and degradation of the enzyme and enhance the search for possible genetic heterogeneity of the enzyme among individuals suspected to have genetic obesity.

The enzymes involved in lipid metabolism in adipose tissue have been extensively studied $(22,29,30,33,38,39,40,46,49)$; however, the so-called hormone sensitive lipase (HSL) has proved difficult to obtain in sufficiently high purity for characterization. In the crude preparation, it appears tightly bound to large lipid- rich particles from which it is difficult to separate (34). Recently, it has become possible to extensively purify and characterize the enzyme in the adipose tissue of the rats and the chicken (14-16, $24,34,35)$. The $\mathrm{pH}$ optima for the extensively purified ( 2000 -fold) rat enzyme and the partially purified (35-fold) human enzyme were 7.0 and 7.4 , respectively $(24,25,26)$. In vitro studies with human adipose tissue and isolated cells suggest that HSL is, indeed, very active in the human adipose tissue but the literature on the subject appears to suggest that there is no uniform system for reporting specific activity of human HSL. Some report activity per wet weight $(6,7,19,32,43,44,47)$, others per lipid content $(8,9,36)$, others per isolated cell $(8,10-13)$ and still others per packed cell volume $(13,20,41)$; only an occasional study (8) expresses HSL activity on more than one basis.

Few studies have reported on the HSL activity of cultured rat adipocytes (18) and none on the enzyme in cultured human cells; although by contrast, lipoprotein lipase activity of cultured human and rat adipocytes has been studied $(17,18,27,45,50)$. In this study, we have devised a new but simple perifusion technique, designed to minimize the known inhibitory effect of free fatty acids on adipose tissue lipolysis $(4,5,23,28)$. We have employed this technique to examine the activity of HSL in whole human adipose tissue and in the adipose cells isolated from the tissue. We have also studied the activity of HSL in cultured human adipocytes.

\section{MATERIALS AND METHODS}

Adipose tissue $(0.5-5 \mathrm{~g})$ was obtained from the subcutaneous tissue of the abdominal wall (15 samples), the upper thigh (6 samples) and the ankle ( 2 samples) from 23 children aged 1-12 years. The children were free of nutritional or metabolic diseases. They were undergoing scheduled elective operative procedures and the samples were excised at the onset of operation and transferred immediately to the laboratory.

The tissues were divided into three portions of similar weight. The first two portions were incubated with collagenase (52) to isolate adipocytes as previously described $(1,2)$. The isolated cells from the first portion were cultured also as previously described $(2,3)$. Isolated cells were counted in an inverted cell counting chamber on plastic coverslips. The cell yield was $8.0 \pm 1.7 \times 10^{5}$ cells per $g$ wet tissue and $1.3 \pm 0.3 \times 10^{6}$ cells per ml packed cells (mean \pm S.D., $n=21$ ). Glass coverslips were found unsuitable for adipose cell counting as the cell membrane is extremely fragile on contact with glass. The third tissue portion was cut into small (approximately $50 \mathrm{mg}$ ) pieces. The cut pieces and the isolated cells from the second portion were each divided into a number of equal subportions determined by the original tissue size and the types of studies anticipated. On each sample, however, cell culture was attempted. Basal and hormone stimulated lipolytic rates were determined on the whole tissue and on the isolated cells. Preliminary experiments using various concentrations of epinephrine 
$\left(10^{-2}\right.$ to $\left.10^{-7} \mathrm{M}\right)$ and theophylline $\left(10^{-2}\right.$ to $\left.10^{-6} \mathrm{M}\right)$ singly and in combination established that maximal stimulation was obtained with $5 \mu \mathrm{M}$ epinephrine alone; theophylline alone at an optimal concentration of $0.5 \mathrm{mM}$ also caused significant stimulation of lipolysis although less than that obtained with $5 \mu \mathrm{M}$ epinephrine (see "Results"). Because the addition of theophylline to epinephrine did not enhance the stimulatory effect of epinephrine at its optimal concentration ( $5 \mu \mathrm{M})$, subsequent stimulation experiments were performed with $5 \mu \mathrm{M}$ epinephrine alone (see "Results").

Studies on tissues and isolated cells. In an attempt to minimize the problem of free fatty acid inhibition of lipolysis in stimulated tissue and cells, an apparatus (Fig. 1) was devised. This apparatus, which permitted several experiments to be performed at one time, consisted of multiple 12-ml graduated polypropylene minicolumns (53) each fitted with a $35 \mu$ filter at its tip and attached by polyethylene tubing $(2.5 \mathrm{~mm} \mathrm{ID})$ to a 20 -channel peristaltic cassette pump (54). Channels were capable of delivering medium at rates from $0.25-500 \mathrm{ml}$ per $\mathrm{h}$. The intake end of the tubing was
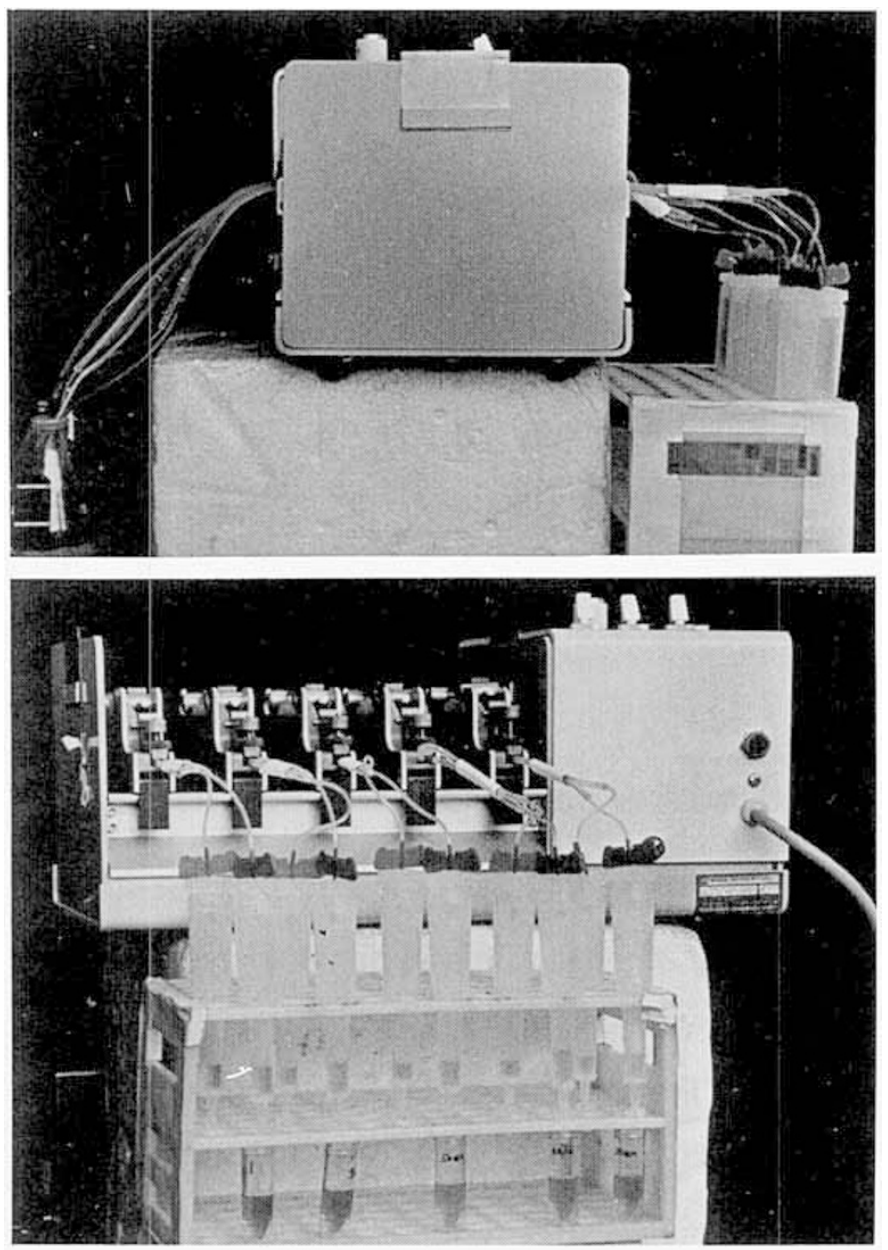

Fig. 1. Top: side view of the perifusion apparatus showing, on the left, $50-\mathrm{ml}$ flasks containing perifusion medium. A polyethylene tube, emerging from each flask, passes through the peristaltic pump (center), set to deliver at desired flow rate. On the right, each polyethylene tube emerges from the pump and is inserted, by a 25-gauge butterfly needle, into the cap of a $12-\mathrm{ml}$ polypropylene minicolumn containing $0.2 \mathrm{ml}$ medium and tissue fragments or cells. Each column is fitted with a $35-\mu$ filter at its tip. The medium, after bathing the cells or tissue fragments, is collected in 3-ml sample vials, which are changed at desired intervals. The volume of each vial is accurately measured to determine the precise flow rate in each channel. Bottom: Front view of the apparatus showing additional details of the cassettes, the pump, the minicolumns, and the collecting sample vials. The pump is capable of holding a maximum of ten cassettes, each of which can accept two polyethylene tubes (internal diameters, $0.5 \mathrm{~mm}$ ) for a maximum of 20 channels. The picture shows ten channels. inserted into a flask containing the incubation medium, with or without effectors (epinephrine and/or theophylline). The tubing was passed through the pump and the exit end was attached to a butterfly needle ( 25 gauge) inserted into the cap of the column. Incubation medium $(200 \mu \mathrm{l})$ was placed into the column and cut pieces of tissue ( $250 \mathrm{mg}$ wet weight) or $250-300 \mu \mathrm{l}$ of packed cells (approximately $25 \times 10^{5}$ cells) were gently introduced on top of the medium. A 25-gauge syringe needle was inserted into the column tip and placed into a 3-ml plastic sample vial which could be changed at desired sampling intervals. The tissues or cells were then perifused under constant pressure with medium at rates which were readily controlled. Each sample collected was accurately measured in order to determine the precise flow rate in each channel at any particular moment. The entire system was placed in an incubator at $37^{\circ} \mathrm{C}$ in an atmosphere of $5 \% \mathrm{CO}_{2}$ and $95 \%$ air. From preliminary studies, a perifusion rate of $5-10 \mathrm{ml}$ per $\mathrm{h}$ was found to be ideal and all perifusion experiments were performed in this range. After equilibrating for $10 \mathrm{~min}$ at $37^{\circ} \mathrm{C}$, samples were collected at $1-5-\mathrm{min}$ intervals for the first $15 \mathrm{~min}$ and at $15-\mathrm{min}$ intervals thereafter for as long as $1 \mathrm{~h}$. The collected samples were either immediately assayed or kept frozen at $-70^{\circ} \mathrm{C}$ for later assay of glycerol by the method of Chernick (21). Preliminary studies (results not shown), in which we compared the standard incubation method with the perifusion method, established that there was no difference in the lipolytic rates of a few tissue samples under basal or epinephrine-stimulated conditions; however, we chose to employ the perifusion technique in our studies because of its simplicity and the opportunity it offered to study the same tissue sample under several different conditions.

In some experiments after the perifusion, the tissues were removed, washed with buffer, quickly blotted dry, weighed and homogenized under ice in an equal volume of $50 \mathrm{mM}$ sodium phosphate buffer, pH 6.9 containing $1 \mathrm{mM}$ EDTA. The homogenate was centrifuged at $20,000 \times g$ at $4^{\circ} \mathrm{C}$ for $20 \mathrm{~min}$. The aqueous supernatant $\left(\mathrm{S}_{20}\right)$ fraction below the upper fat cake was removed for immediate assay or kept frozen at $-70^{\circ} \mathrm{C}$ for later assay of HSL by a modification of the method of Khoo and Steinberg (33) described below.

Studies on the cultured cells. The cultured cells were first subcultured after an initial period of 1-4 wk. They were subsequently subcultured at confluence and the medium changed every 3-4 days. After the fourth passage, some cells were maintained in the regular medium which consisted of RPMI 1640 with $10 \%$ fetal calf serum (FCS), penicillin $(1 \mathrm{unit} / \mathrm{ml})$ and streptomycin $(1 \mu \mathrm{g} / \mathrm{ml})$. Others were grown in a fat-enriched medium, made up of M199 fortified with $20 \%$ FCS, $0.75 \mathrm{mM}$ linoleic acid, $10 \mathrm{mM}$ glucose $200 \mu$ units insulin $/ \mathrm{ml}$, penicillin, and streptomycin. The cultured cells were studied at weekly intervals after the fourth passage for up to $8 \mathrm{wk}$.

Hormone stimulation of the cultured cells was performed as follows. Replicate monolayer cells in T-150 flasks were drained of medium and washed three times with serum-free medium. Then $15 \mathrm{ml}$ of serum-free RPMI 1640 with $5 \%$ BSA with (stimulated) and without (basal) epinephrine $(5 \mu \mathrm{M})$ were added. The cells were incubated for $30 \mathrm{~min}$; immediately washed six times with 50 $\mathrm{mM}$ sodium phosphate buffer, $\mathrm{pH} 6.9$, and then lysed by freezing and thawing four times in distilled water $(3 \mathrm{ml} / \mathrm{flask})$. The lysate was centrifuged at $20,000 \times g$ at $4^{\circ} \mathrm{C}$ for $20 \mathrm{~min}$. The aqueous supernatant $\left(\mathbf{S}_{20}\right)$ fraction was removed for immediate assay or kept frozen at $-70^{\circ} \mathrm{C}$ for later assay of HSL by a method modified from Khoo and Steinberg (33) described below.

Activation of $H S L$ enzyme in the $S_{20}$ fractions. We adapted the method of Khoo and Steinberg (33) to the measurement of HSL in the $\mathrm{S}_{20}$ fraction of both the tissue homogenate and cultured cell lysates. The enzyme source was incubated (activated) at room temperature for $10 \mathrm{~min}$ in a total volume of $100 \mu \mathrm{l}$ of a mixture containing $25 \mathrm{mM}$ Tris- $\mathrm{HCl}$ buffer, $\mathrm{pH} 8.0,5 \mathrm{mM}$ magnesium acetate, $1 \mathrm{mM}$ EDTA, $2 \mathrm{mM}$ dithiothreitol, $0.5 \mathrm{mM}$ ATP, 0.01 $\mathrm{mM}$ cyclic AMP, $150 \mathrm{~g} / \mathrm{ml}$ protein kinase (cyclic AMP dependent) and $25-50 \mu \mathrm{g}$ protein. The nonactivated enzyme mixture was similarly incubated, but in the absence of ATP, cyclic AMP, and 
protein kinase. The controls lacked the enzyme protein but contained all other ingredients.

Assay of HSL enzyme in the $S_{20}$ fractions. After 10 min activation, as described above, $200 \mu$ l of a substrate mixture was added, which contained $10^{-4} \mathrm{M}$ triolein sonicated in 5\% gum arabic and $0.5 \%$ BSA dissolved in $50 \mathrm{mM}$ sodium phosphate buffer, $\mathrm{pH} 7.4$. The glycerol formed in this reaction mixture was monitored spectrophotometrically by monitoring the decrease in NADH absorbance at $340 \mathrm{~nm}$ by a modification of the method of Pinter et al. (42). In this modification, the assay was performed by adding to the $300 \mu \mathrm{l}$ of enzyme-substrate mixture, $1.5 \mathrm{ml}$ of a reaction mixture containing $3 \mathrm{mM}$ magnesium sulfate, $1 \mathrm{mM}$ potassium chloride, $0.25 \mathrm{mM}$ ATP, $0.2 \mathrm{mM}$ NADH, $2 \mathrm{mM}$ PEP (tri-monocyclohexylammonium salt), 6 units/ml $\mathrm{LDH}$, and 1.3 units $/ \mathrm{ml}$ pyruvate kinase in $50 \mathrm{mM}$ triethanolamine- $\mathrm{HCl}$ buffer, $\mathrm{pH} \mathrm{7.4.}$ The total reaction mixture was shaken rapidly and initial absorbance (Al) read at $340 \mathrm{~nm}$ at room temperature in a Hitachi digital reccrding spectrophotometer model 191. Then $18 \mu \mathrm{l}$ of glycerol kinase $(150 \mu / \mathrm{ml})$ was added to initiate the reaction which was then monitored by recording absorbance (A2) at 5-min intervals for $30 \mathrm{~min}$ at room temperature. Glycerol standards (0-200 nmole/

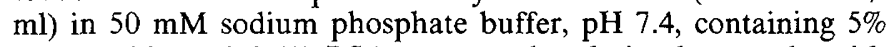
gum arabic and $0.5 \%$ BSA were analyzed simultaneously with each set of determinations. The reaction was usually complete within $5 \mathrm{~min}$ in the absence of new glycerol formation; however, new glycerol formed by the action of HSL enzyme on triolein could be followed for as long as $2-3 \mathrm{~h}$. The rate of glycerol formation between 15-30 min was used for data analysis.

From preliminary studies employing a $\mathrm{pH}$ range from 6.5-8.0, maximal activity of HSL was found at $\mathrm{pH} 7.4$ and this $\mathrm{pH}$ was employed in all subsequent determinations. Also from preliminary investigations, triolein at concentrations from $10^{-2}$ to $10^{-8} \mathrm{M}$ was employed. Maximal enzyme activity was observed over a broad range $\left(10^{-6}\right.$ to $\left.10^{-4} \mathrm{M}\right)$ of triolein concentration; triolein at a concentration of $10^{-4} \mathrm{M}$ was employed in all subsequent determinations in order to ensure an adequate amount of substrate in the reactions. The enzyme activity was also linear over a wide range $(5-100 \mu \mathrm{g})$ of enzyme protein content in the reaction mixture. Therefore, the enzyme substrate mixture was designed to contain $25-50 \mu \mathrm{g}$ protein in all experiments.

Protein in the $S_{20}$ fractions was assayed by the method of Lowry et al. (37). Specific activity, expressed as nmole of glycerol formed or released per min, was determined per $g$ tissue wet weight, per $10^{6}$ cells or per $\mathrm{mg}$ protein in the $\mathrm{S}_{20}$ fraction.

The data were analyzed by paired $t$ test and significance assigned where the $P$ value was less than 0.05 . Also, when appropriate, regression analysis of paired data was performed.

\section{RESULTS}

Whole tissue and isolated adipocytes. Figure 2 demonstrates that incubating whole tissue or isolated cells with epinephrine $(5 \mu \mathrm{M})$ or theophylline $(0.5 \mathrm{mM})$ or both produced significant increases in the specific activity of HSL. In the whole tissue, epinephrine alone caused a 5.4-fold increase over basal activity and was more effective as a stimulant than theophylline alone, which produced a 1.8 -fold increase or a combination of both which produced a 3.3-fold increase. In isolated cells, similar results were obtained. Epinephrine alone, which produced a 4.5 -fold increase over basal, proved more effective as a lipolytic stimulant than tneophylline alone, which caused a 1.7-fold increase or a combination of both which caused a 2.5 -fold increase over basal levels.

In Figure 3, a significant direct relationship is demonstrated between basal and effector-stimulated lipolysis for $5 \mu \mathrm{M}$ epinephrine and/or $0.5 \mathrm{mM}$ theophylline in the whole tissue and in the isolated cells.

The cultured cells. Figure 4 shows the appearance of a typical cultured adipose cell line after $6 \mathrm{wk}$ in culture when it has become essentially lipid-free $(a)$. The same cell line shows progressive lipid

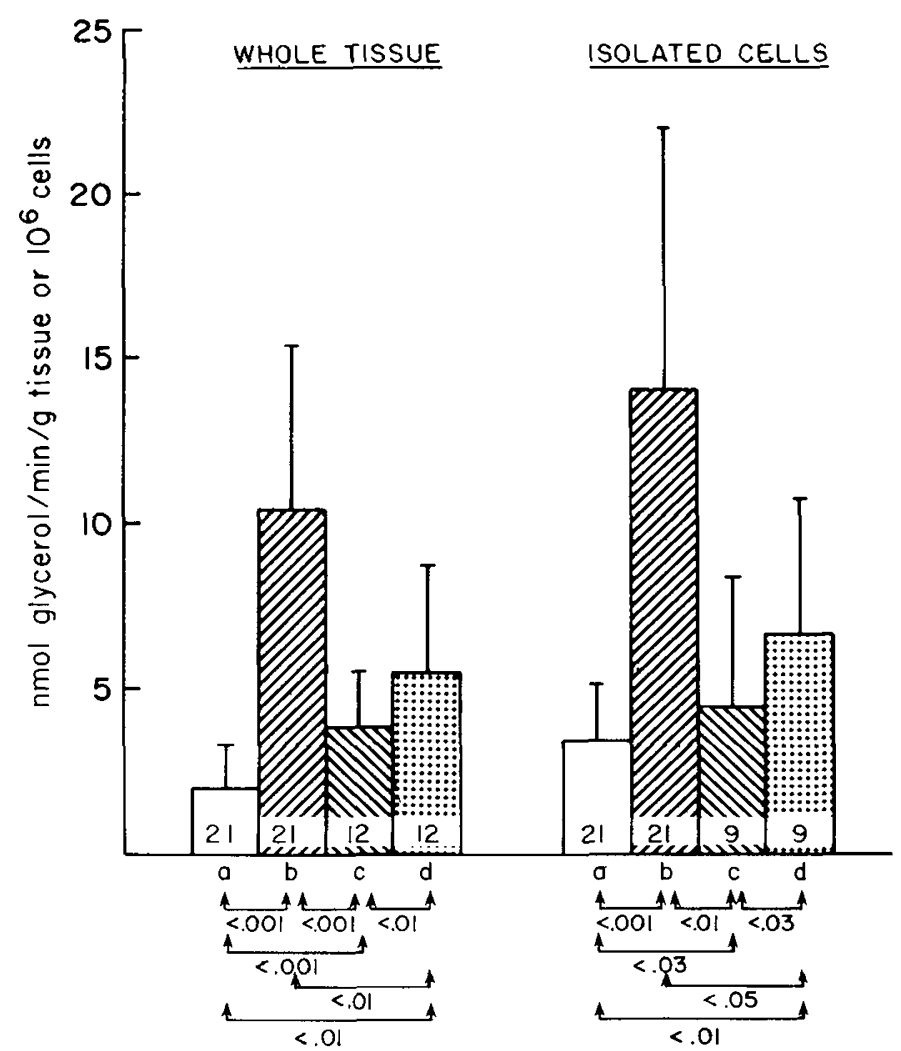

Fig. 2. Effect of epinephrine and theophylline on lipolysis in whole adipose tissue and in cells isolated from adipose tissue. Cells (or tissues) were incubated for $60 \mathrm{~min}$, as described in "Materials and Methods," in the absence of any effectors $(a)$ or in the presence of $5 \mu \mathrm{M}$ epinephrine $(b)$ $0.5 \mathrm{mM}$ theophylline $(c)$ or both $(d)$. Glycerol release was measured, as described in "Materials and Methods." Results are expressed as mean \pm S.D. for the number of samples indicated at the bottom of each bar. Values below the graph indicate the $P$ value for the paired $t$ test comparing the means between the two treatments joined by each pair of arrows.

reaccumulation when grown in the presence of free fatty acids for $24(b)$ and for 7 days $(c)$.

The basal specific activity of HSL in the $S_{20}$ fraction of lysates of cells grown in fat-enriched medium was similar to that in the $S_{20}$ fraction of the original tissue and was twice that in the $S_{20}$ fraction of lysates of cells grown in the regular medium (Fig. 5).

When the cultured cells were stimulated in vitro for $30 \mathrm{~min}$ with $5 \mu \mathrm{M}$ epinephrine and then lysed, the specific activity of HSL in the $S_{20}$ fraction of lysates of cells grown in fat-enriched and in regular medium doubled. The HSL activity in the $S_{20}$ fraction of the stimulated original tissue increased 4-fold over basal, attaining values which were twice those in the $S_{20}$ fractions of lysates of cells grown in the fat-enriched medium and four times those in the $S_{20}$ fraction of lysates of cells grown in the regular medium (Fig. 5).

Enzyme activation. As shown in Table 1, HSL was slightly (8$15 \%$ ) but significantly activated in all $S_{20}$ fractions of tissue homogenates and cell lysates incubated basally in vitro. Upon activation, there was a mean increase of $11 \%$ in the enzyme activity of basally incubated tissue $(n=10, P<0.001)$, a mean increase of $15 \%$ in enzyme activity of basally incubated cells grown in regular medium $(n=10, P<0.002)$ and a mean increase of $8 \%$ in the enzyme activity of basally incubated cells grown in fat-enriched medium $(n=6, P<0.03)$. On the other hand, when the tissues and cells had been epinephrine-stimulated in vitro before homogenization and lysis respectively, the increases in activity found on activation of the enzyme in the respective $S_{20}$ fractions were very small (3-7\%) and not significant: whole tissue $(n=10, P>0.1)$, 


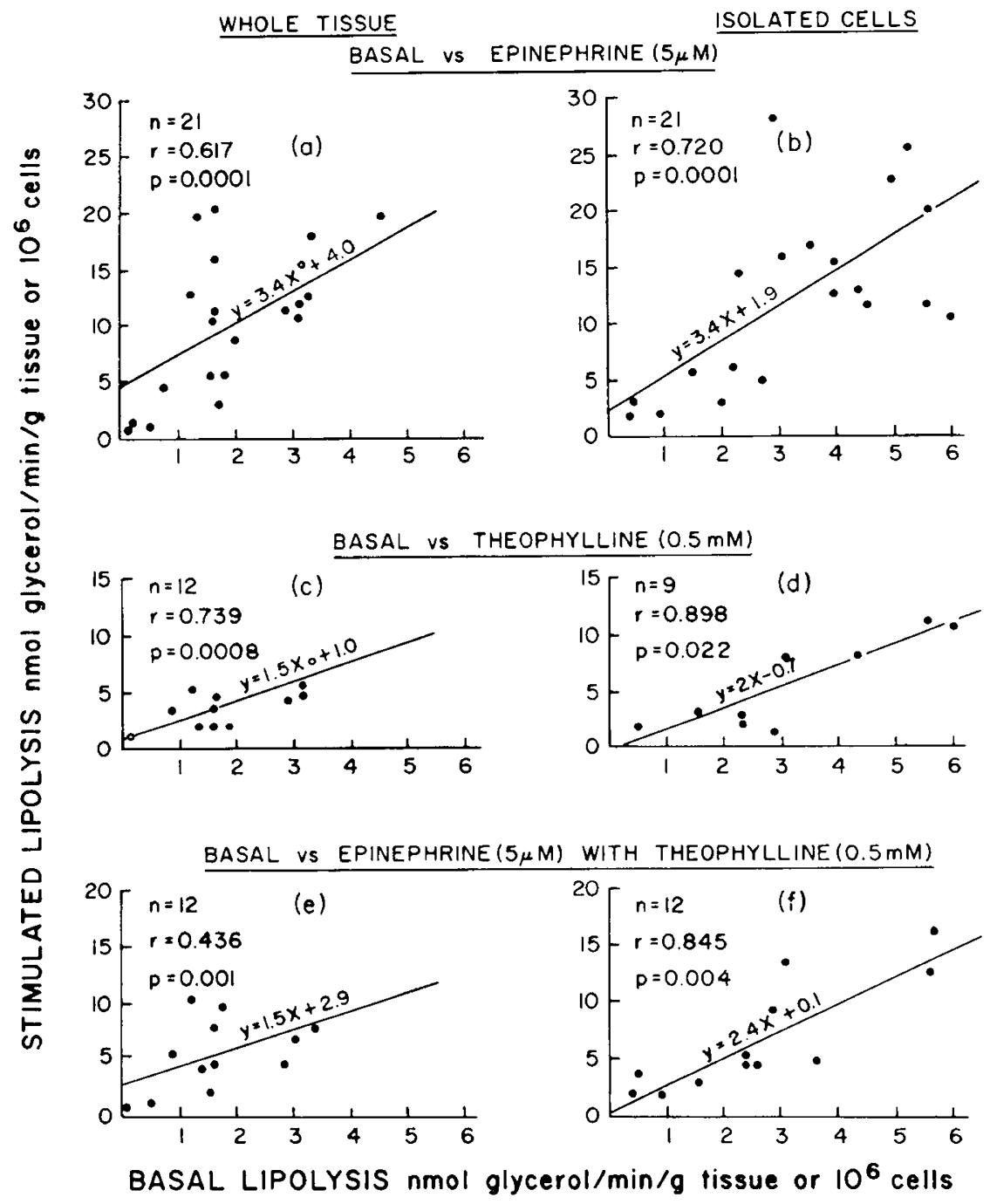

Fig. 3. Relationship between basal and effector-stimulated lipolysis in whole adipose tissue and in cells isolated from adipose tissue. Whole adipose tissue or isolated adipose cells were incubated as described in "Materials and Methods" in the absence (basal) or presence of $5 \mu \mathrm{M}$ epinephrine and/or $0.5 \mathrm{mM}$ theophylline. Basal and effector-stimulated lipolysis were plotted for each tissue or cell sample. In isolated cells and in whole tissue respectively, basal lipolysis was compared with epinephrine-stimulated lipolysis $(a$ and $b$ ), with theophylline-stimulated lipolysis $(c$ and $d$ ) and with lipolysis stimulated by both ( $e$ and $f$ ). For each set of values compared, the regression equation derived has been shown on the regression line and the number of samples compared $(n)$, the correlation coefficient $(r)$ and the $P$ value have also been shown.

cells in fat-enriched medium $(n=6, P>0.05)$ cells in regular medium $(n=10, P>0.05)$.

\section{DISCUSSION}

Adipose tissue perfusion technique has been employed at least twice previously $(5,48)$ and found useful in helping to establish the time relationship between the attainment of maximal intracellular cyclic AMP concentration and maximal cellular lipolytic rate (5). It has also been employed to establish the concentration of adenosine necessary to induce adenosine lipolytic inhibition in adipose tissue (48). The particular perfusion method we have employed is different from that previously employed by others $(5$, 48) although it shares in the advantage that it is a simple technique which allows several studies to be performed on the same samples simultaneously and consecutively. The value of HSL obtained using this technique is similar to the values obtained using the standard incubation technique on the same samples (results not shown). Our data are in general agreement with previously reported levels of HSL in human adipose tissue and cells, whether expressed per $g$ wet tissue $(6,7,19,32,43,47)$ or per cell $(8,10$ $13,31)$.

Studies of adipose tissue HSL have generally been limited to the whole tissue and isolated cells. In this study, we have attempted to establish the fate of this enzyme in cultured cells as well. Higher levels of HSL activity in cultured cells were found in those cells grown in the fat-enriched medium; however, whether cultured in regular or enriched medium, significant levels of basal HSL activity were retained in the cells. These basal levels increased significantly when the cells were stimulated in vitro by epinephrine. It is interesting that the cells with the highest levels of basal and epinephrine-stimulated HSL activities were those grown in the fat-enriched medium and had showed the morphologic changes associated with adipose conversion as seen by us (Fig. 4) and also previously described by others $(50,51)$. The cells grown in the enriched medium had basal levels of HSL activity similar to those in the original tissue and, although they did not respond to epinephrine stimulation as markedly as did the original tissue, nevertheless, they responded briskly by doubling, on stimulation, their HSL activity over basal.

In this study, we noted that although theophylline by itself significantly stimulated lipolysis nearly 2 -fold over basal, it ap peared to blunt or reduce the epinephrine effect on adipose tissue and cells when combined with epinephrine. This observation was consistently noted throughout and, at the present time, there is no ready explanation for it, especially in view of the assigned role of 


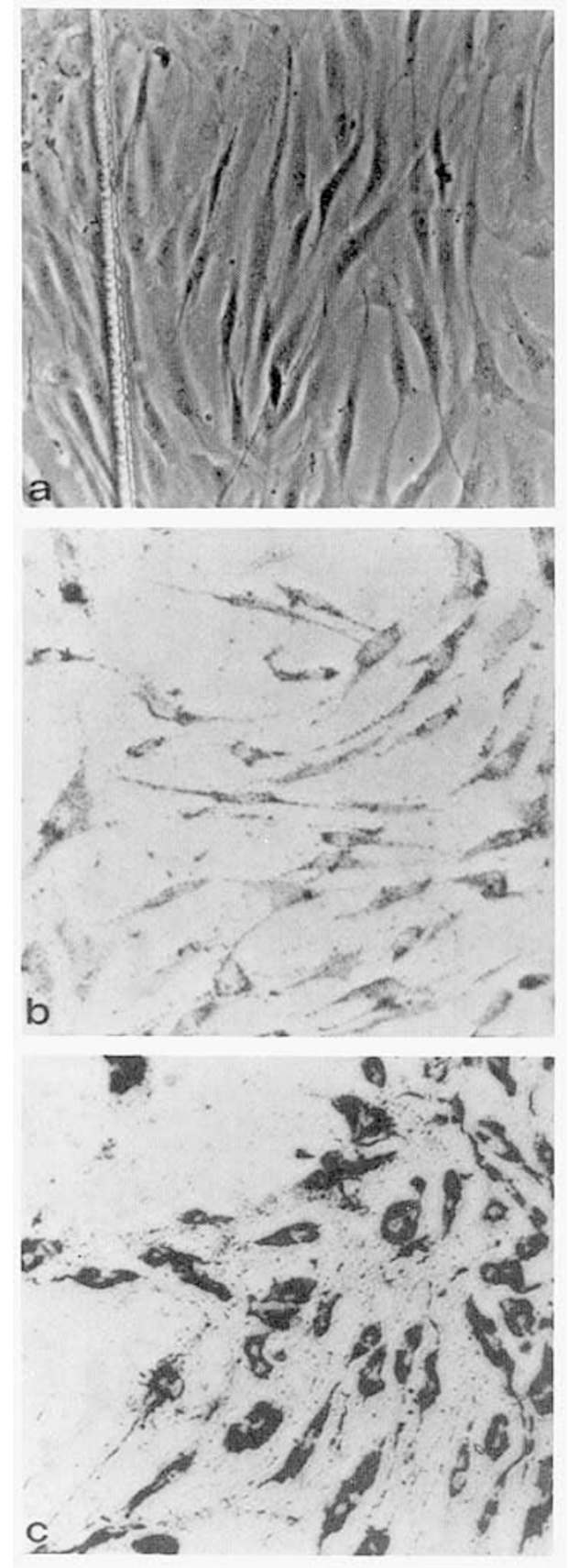

Fig. 4. (a) Cultured adipocytes from a 7-year-old girl (Oil-Red-O stained) $6 \mathrm{wk}$ after initial culture and subcultured four times in regular medium (see "Materials and Methods"). The cells have assumed the usual fibroblast appearance and little intracellular neutral lipid remains $(\times 100)$. (b) Cultured adipocytes as in (a), but grown for $24 \mathrm{~h}$ in fat-enriched medium (see "Materials and Methods"). The cells (stained) remain fibroblast-like in appearance, but now show small intracellular neutral lipid droplets $(\times 100)$. (c) Cultured adipocytes as in $(b)$, grown for 7 days in fatenriched medium. Note that the cells have become more rounded in appearance, massively engorged with large amounts of intracellular neutral lipid. The nucleus in some cells appears to be located at the periphery $(\times 100)$. Further exposure to fat-enriched medium for an additional 7 days caused no further intracellular lipid-accumulation.

theophylline as a phosphodiesterase inhibitor. It would be expected to enhance lipolysis by inhibiting the enzyme which degrades cyclic AMP, thus effecting an accumulation of intracellular cyclic AMP. But, as noted earlier, there is a significant time lag between the attainment of maximal intracellular cyclic AMP concentration and the onset of maximal lipolysis in rat adipose cells (5), suggesting that factors other than intracellular cyclic
AMP concentration may be important to the lipolytic process. Although our data did not establish a direct relationship between adipose tissue HSL activities and the ages of the donor children $(r=0.30, n=21, P>0.05)$ we did find a consistent and significant direct relationship between basal and stimulated (epinephrine and/or theophylline) HSL activities in the adipose tissue and cells of these children. The higher the basal activity of HSL in the adipose cell, the greater was the response to epinephrine and/or theophylline stimulation. In our own studies, we did not systematically measure the cell size; however, we did note that the smallest appearing cells (deriving from the heels and thighs) had the lowest basal and effector-stimulated HSL activities. In adults, a significant direct relationship has been previously reported between basal and hormone-stimulated lipolysis in human adipose tissue $(31,32)$. In addition, a direct relationship was also found by the same investigators $(31,32)$ between basal and hormone-stimulated lipolysis on the one hand and adipose cell size on the other.
BASAL
INCUBATION

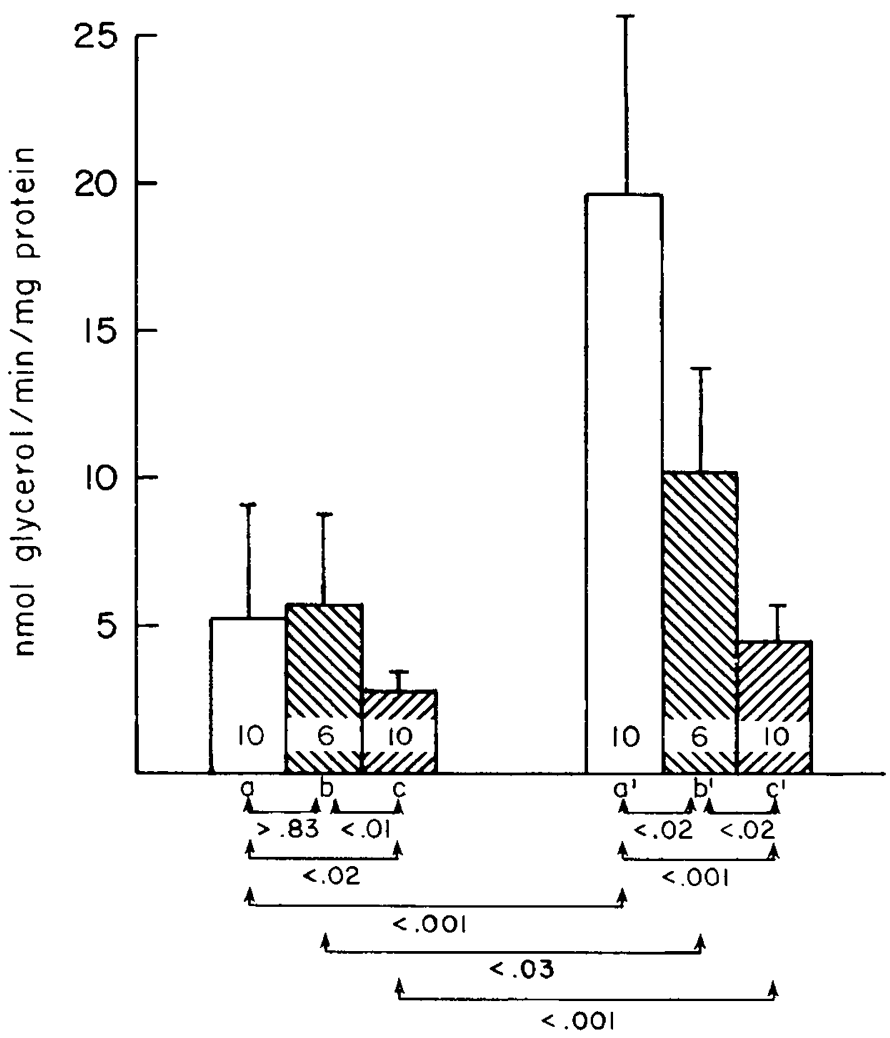

Fig. 5. Effect of in vivo incubation with epinephrine on the hormonesensitive lipase in the aqueous fractions of adipose tissue and cultured adipose cells grown on regular and fat-enriched medium. Whole tissues were incubated as described in "Materials and Methods" in the absence (a) or presence $\left(a^{\prime}\right)$ of $5 \mu \mathrm{M}$ epinephrine. The cells were thoroughly washed and homogenized and the $\mathrm{S}_{20}$ fractions (see "Materials and Methods") assayed for hormone-sensitive lipase as described. Isolated cells were cultured as described in "Materials and Methods." Ten lines were grown in regular medium, six of these in fat-enriched medium as well. For these experiments, paired flasks of cells grown in fat-enriched medium were incubated for $30 \mathrm{~min}$ in the absence $(b)$ or presence $\left(b^{\prime}\right)$ of epinephrine. Paired flasks of cells grown in regular medium were also incubated for 30 min in the absence $(c)$ or presence $\left(c^{\prime}\right)$ of epinephrine. The cells were washed carefully and lysed and the $S_{20}$ fractions (see "Materials and Methods") were assayed for hormone-sensitive lipase. Results are expressed as mean \pm S.D. for the number of cell lines indicated at the bottom of each bar. Each cell line was studied at least twice. Values below the graph indicate the $P$ values for the paired $t$ test comparing means between the two treatments joined by each pair of arrows. 
Table 1. Activation of hormone-sensitive lipase activity in the cell-free system employing the $S_{20}$ fraction of tissue homogenates and cultured cell lysates ${ }^{1}$

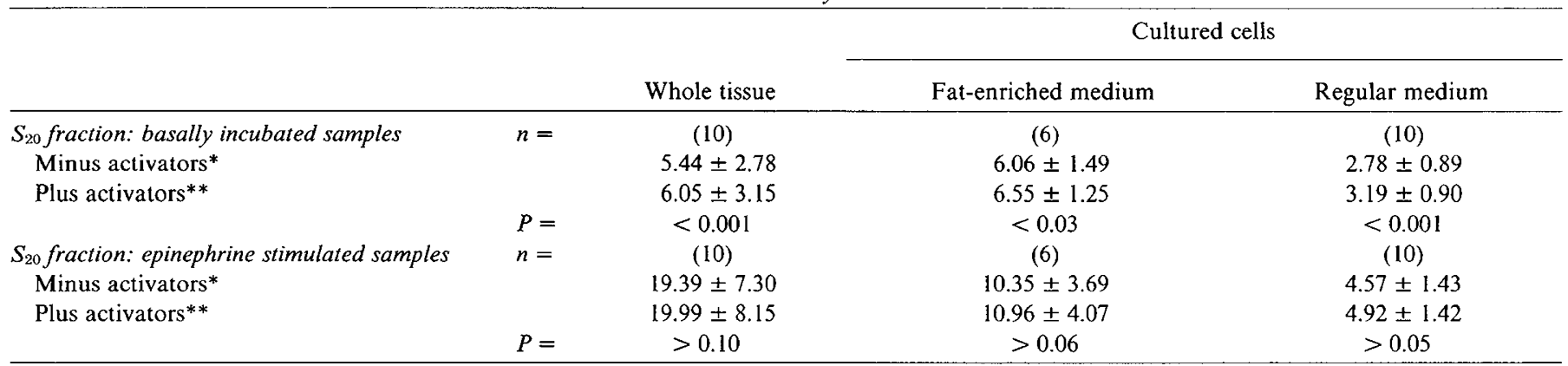

${ }^{1}$ Whole tissue and cultured cells were fractionated as described in "Materials and Methods" after incubation in the absence (basal) or presence of 5 $\mu \mathrm{M}$ epinephrine for $30 \mathrm{~min}$ in vitro. The $\mathrm{S}_{20}$ fractions (see "Materials and Methods") were assayed in the absence (minus activators)* and presence (plus activators)** of ATP, cAMP, and protein kinase (see "Materials and Methods"). Results are expressed as mean \pm S.D. for the number ( $n$ ) of tissue samples or cell lines studied. The $P$ value relates to the paired $t$ test comparing the same samples treated with or without activators.

Further, James et al. (32) reported a direct relationship between basal and hormone-stimulated lipolysis and the degree of obesity.

Our data suggest that HSL in the crude $S_{20}$ fraction can be activated. The degree of activation, however, appears low, attaining statistical significance when the preparation was derived from basal incubation but not when the preparation had been epinephrine-stimulated in vitro. The difference appears to be due to the fact that the \% increase in activity due to activation was greater in the basal than in the epinephrine-stimulated samples. We expect that it would be possible to effect higher activation with greater purification of the enzyme protein.

Hormone sensitive lipase has proved difficult to purify and characterize; however, the enzyme has been extensively purified (2000-fold) in the rat adipose tissue and somewhat less so (300fold) in the chicken adipose tissue. The enzyme from the rat tissue has been characterized with respect to its molecular weight (14, $15,24)$, its isoelectric point $(14,15,34)$, its Stokes radius (15), and a few of its inhibitors $(24,34)$. Activation of the rat enzyme was achieved by phosphorylation of the enzyme protein $(15,24)$. In man, it has been difficult to conduct the same studies because of the inordinately large quantity of fat tissue needed for such studies. It is encouraging to find that cultured human adipocytes retain high enough HSL activity so that they can be grown in sufficiently large quantity in order to obtain enough protein for purification and characterization. Some potential advantages are inherent in the use of the culture method to study the HSL activities in human adipose tissue, particularly in the individual patients who might be suspected to have genetic or familial obesity. It would enable us to undertake a search for genetic heterogeneity of HSL among such individuals. Finally, this method may be very useful in our efforts to clarify the cellular mechanisms involved in the synthesis, transport and degradation of hormone-sensitive lipase in the human adipose cell.

\section{REFERENCES AND NOTES}

1. Adebonojo, F. O.: Enzymatic adaptations by cultured adipocytes of human infants and children: Effect of obese serum on the activities of lactate-, malateand glucose-6-phosphate dehydrogenases. Pediatr. Res., 9: 889 (1975).

2. Adebonojo, F. O.: Monolayer cultures of disaggregated human adipocytes. In Vitro, 11: 50 (1976).

3. Adebonojo, F. O.: Triglyceride mobilization in cultured adipocytes of human infants. Biol. Neonate, 29: 7 (1976).

4. Allen, D. O.: Role of albumin in hormone-stimulated lipolysis. Biochem. Pharmacol., 28: 733 (1979)

5. Allen, D. O., Largis, E. E., Miller, E. A., and Ashmore, J.: Continuous monitoring of lipolytic rates in perfused isolated fat cells. J. Appl. Physiol., 34: 125 (1973).

6. Arner, P., Arner, O., and Ostman, J.: The effect of local anesthetic agents on lipolysis by human adipose tissue. Life Sci., 13: 161 (1973).

7. Arner, P.: Relationship between intracellular cyclic AMP and lipolysis in human adipose tissue. Acta Med. Scand., 200: 179 (1976).

8. Arner, P. and Ostman, J.: Abnormalities in the adrenergic control and the rate of lipolysis in isolated human subcutaneous adipose tissue in Diabetes Mellitus. Diabetologia, 12: 593 (1976)

9. Arner, P., Wennlund, A., and Ostman, J.: Thyroid hormone regulators of the catecholamine effects in human adipose tissue. Acta Endocrinol., 96: 65 (1981).
10. Arner, P. and Ostman, $\mathbf{J} .:$ Changes in the adrenergic control and the rate of lipolysis of isolated human adipose tissue during fasting and after refeeding. Acta Med. Scand., 200: 273 (1976).

11. Arner, P., Wennlund, A., and Ostman, J.: Regulation of lipolysis by human adipose tissue in hyperthyroidism. J. Clin. Endocrinol. Metab., 48: 415 (1979).

12. Arner, P., Engfeldt, P., and Ostman, J.: Blood glucose control and lipolysis in Diabetes Mellitus. Acta Med. Scand.. 208: 297 (1980)

13. Arner, P. and Ostman, J.: Importance of the cyclic AMP concentration for the rate of lipolysis in human adipose tissue. Clin. Sci., 59: 199 (1980).

14. Belfrage, P., Jergil, B., Stralfors, P., and Tornquist. H.: Hormone-sensitive lipase of rat adipose tissue: Identification and some properties of the enzyme protein. FEBS Letters, 75: 259 (1977).

15. Belfrage, P., Jergil, B., Stralfors, P., and Tornquist, H.: Identification and some characteristics of the enzyme protein of the hormone-sensitive lipase from rat adipose tissue. Adv. Exp. Biol. Med., 101: 113 (1978).

16. Berglund, L., Khoo, J. C., Jensen, D., and Steinberg, D.: Resolution of hormonesensitive triglyceride/diglyceride lipase from monoglyceride lipase of chicken adipose tissue. J. Biol. Chem., 255: 5420 (1980).

17. Bjorntorp, P., Karlsson, M., Pettersson, P., and Sypniewska, G.: Differentiation and function of rat adipocyte precursor cells in primary culture. J. Lipid Res., 21: 714 (1980)

18. Bjorntorp, P.. Karlsson, M., Pertoft, H., Pettersson, P., Sjostrom, L., and Smith, U.: Isolation and characterization of cells from rat adipose tissue developing into adipocytes. J. Lipid Res., 19: 316 (1978).

19. Burns, T. W., Terry, B. E., Langley, P. E., and Robinson, G. A.: Role of cyclic AMP in human adipose tissue lipolysis. Adv. Cyclic Nucl. Res., 12: 329 (1980).

20. Burns, T. W. and Hales, C. N.: Regulation of lipolysis in isolated human adipose tissue cells. Lancet, $1: 796$ (1966)

21. Chernick, S. S.: Determination of glycerol in acyl glyerols. Methods in Enzymology, Vol. XIV. pp 627-630 (1969).

22. Chmelar, $M$. and Chmelarova, M.: Multiple forms of hormone-sensitive lipase in different rat tissues. FEBS Symposium, 18: 215 (1980).

23. Fain, J. N. and Shepard, R. E.: Hormonal regulation of lipolysis: Role of cyclic nucleotides, adenosine and free fatty acids. Adv. Exp. Med. Biol., 111: 43 (1979).

24. Fredrickson, G., Stralfors, P., Osten-Nilsson, N., and Belfrage, P.: Hormonesensitive lipase of rat adipose tissue: Purification and some properties. J. Biol. Chem., 256: 6311 (1981).

25. Giudicelli, H., Pastre, N., and Boyer, J.: Lipolytic activity of adipose tissue, III. The triacylglycerol lipase activity of human adipose tissue: a reevaluation. Biochim. Biophys. Acta, 348: 221 (1974)

26. Giudicelli, H., Combes-Pastre, N., and Boyer, J.: Lipolytic activity of adipose tissue. IV. The diacylglycerol lipase of human adipose tissue. Biochim. Biophys. Acta, 369: 25 (1974).

27. Glick, J. M. and Rothblat, G. H.: Effects of metabolic inhibitors on the synthesis and release of lipoprotein lipase in cultured cells derived from the stromal vascular fraction of rat adipose tissue. Biochim. Biophys. Acta, 618: 163 (1980).

28. Ho, R. J. and Sutherland, E. W.: Formation and release of a hormone antagonist by rat adipocytes. J. Biol. Chem., 246: 6822 (1971)

29. Huttunen, J. K., Ellingboe, J., Pittman, R. C., and Steinberg, D.: Partial purification and characterization of hormone-sensitive lipase from rat adipose tissue. Biochim. Biophys. Acta, 218: 333 (1970)

30. Huttunen, J. K. and Steinberg, D.: Activation and phosphorylation of purified adipose tissue hormone-sensitive lipase by cyclic AMP-dependent protein kinase. Biochim. Biophys. Acta, 239: 411 (1971).

31. Jacobsson, B. and Smith, U.: Effect of cell size on lipolysis and antilipolytic action of insulin in human fat cells. J. Lipid Res., 13: 651 (1972).

32. James, R. C., Burns, T. W., and Chase, G. R.: Lipolysis of human adipose tissue cells: Influence of donor factors. J. Lab. Clin. Med., 77: 254 (1971).

33. Khoo, J. C. and Steinberg, D.: Reversible protein kinase activation of hormonesensitive lipase from chicken adipose tissue. J. Lipid Res., I5: 602 (1974).

34. Khoo, J. C., Berglund, L., Jensen, D., and Steinberg, D.: Hormone-sensitive lipase of rat adipose tissue: Correlation of activity with a protein of molecular weight 84,000. Biochim. Biophys. Acta, 619: 440 (1980). 
35. Khoo, J. C., Drevon, C. A., and Steinberg, D.: Dissociation of the lipid-enzyme complex of hormone-sensitive lipase using high density lipoprotein or apolipoprotein A-1. Biochim. Biophys. Acta, 617: 540 (1980).

36. Lafontan, M. and Berlan, M.: Evidence for the $\alpha_{2}$ nature of the $\alpha$-adrenergic receptor inhibiting lipolysis in human fat cells. Eur. J. Pharmacol., 66: 87 (1980).

37. Lowry, O. H., Rosebrough, N. J., Farr, A. L., and Randall, R. J.: Protein measurement with the Folin-phenol reagent. J. Biol. Chem., 193: 265 (1957).

38. Manganiello, V., Murad, F., and Vaugh, M.: Effects of lipolytic and antilipolytic agents on 3'5'-adenosine. J. Biol. Chem., 246: 2195 (1971).

39. Matsumura, S.: Purification and properties of an adipose tissue triglyceride lipase. Kobe J. Med. Sci., 23: 7 (1977).

40. Nieuwenhuizen, W., Reman, F. C., Vermeer, I. A. M., and Vermond T. Purification and properties of two lipases from pig adipose tissue. Biochim. Biophys. Acta, 431: 288 (1976)

41. Ohisalo, J. J.: Effects of adenosine on lipolysis in human subcutaneous fat cells J. Clin. Endocr. Metab., 52: 359 (1981)

42. Pinter, J. K., Hayashi, J. A., and Watson, J. A.: Enzymic assay of glycerol, dihydroxyacetone and glyceraldehyde. Arch. Biochem. Biophys., I2I: 404 (1967).

43. Reckless, J. P. D. and Galton, D. J.: Catecholamine receptor sensitivity and the regulation of lipolysis in adult diabetes. Diabetologia, 12: 351 (1976).

44. Redding, $\Upsilon$. W. and Schally, A. V.: Effect of hypothalamic preparations on human omental adipose tissue in vitro. Metabolism, 21: 499 (1972).

45. Rothblat, G. H. and DeMartinis, F. D.: Release of lipoprotein lipase from rat adipose tissue cells grown in culture. Biochem. Biophys. Res. Commun., 78: 45 (1977).

46. Severson, D. L., Khoo, J. C., and Steinberg, D.: Role of phosphoprotein phosphatases in reversible deactivation of chicken adipose tissue hormone-sensitive lipase. J. Biol. Chem., 252: 1484 (1977).

47. Sinha, T. K., Thajchayapong, P., Queener, S. F., Allen, D. O., and Bell, N. H.: On the lipolytic action of parathyroid hormone in man. Metabolism, 25: 251 (1976)

48. Solevi, A.: The sensitivity of perifused fat cells to the antilipolytic action of adenosine. Acta Physiol. Scand., 110: 211 (1980).

49. Steinberg, D.: Interconvertible enzymes in adipose tissue regulated by cyclic AMP-dependent protein kinase. Adv. Cycl. Nucl. Res., 7: 157 (1976).

50. Van, R. L. R. and Roncari, D. A. K.: Complete differentiation of adipocyte precursors: A culture system for studying the cellular nature of adipose tissue. Cell Tiss. Res., 195: 317 (1978).

51. Van, R. L. R., Bayliss, C. E., and Roncari, D. A. K.: Cytological and enzymological characterization of adult human adipocyte precursors in culture. J. Clin. Invest., 58: 699 (1976)

52. Millipore Corp., Freehold, NJ.

53. BioRad Laboratories, Richmond, CA.

54. Manostat, New York, NY.

55. All reagents, the sources of which were not otherwise identified, were purchased from Sigma Chemical Corp., St. Louis, MO.

56. This research was supported by a grant from the W.W. Smith Charitable Trust. 57. The authors thank the surgeons and operating room nurses at the Children's Hospital of Philadelphia for their cooperation in obtaining biopsy specimens. 58. The authors thank Madelyn Smith, Jane Coyle, Ra-mond Spencer-Faison and Spencer Brown for their technical assistance.

59. Requests for reprints should be addressed to: Festus O. Adebonojo, M.D., Children's Hospital of Philadelphia, 34th and Civic Center Blvd., Philadelphia PA 19104.

60. Received for publication November 24,1981

61. Accepted for publication July 8, 1982. 